\title{
SUPPLEMENTARY STUDIES ON ANT LARVAE: TERATOMYRMEX ${ }^{1}$
}

\author{
By George C. Wheeler and Jeanette Wheeler \\ Laboratory of Desert Biology \\ Desert Research Institute \\ University of Nevada System \\ Reno 89507
}

The first collector of this Australian genus, T. Greaves, Esq. (in 1942), must have been surprised when he first viewed his specimens under magnification; he probably thought he had collected diseased ants. The describer (J. J. McAreavey 1957) was evidently somewhat astonished for he gave it the name Teratomyrmex, from the Greek teras (teratos) monster, marvel, wonder + myrmex ant. We have in English teratism the worship of monsters, teratology the study of monstrosities and teratoma a tumor derived from more than one embryonic layer and made up of a mixture of tissues. Teratomyrmex is certainly an appropriate name, for the worker looks as if it has a huge tumor on the top of its thorax (see Fig. 7 and 8). Aside from this unique peculiarity the genus is quite ordinary and belongs in the Formicini, an ordinary tribe of Formicinae, which includes such anatomically commonplace genera as Acanthomyops, Lasius and Formica.

The first specimens of Teratomyrmex we have seen were a gift from Rev. B. B. Lowery (of Norwood, South Australia) in 1967. In the accompanying letter he wrote: "I have also taken the liberty of filling up the vacant spaces in the box with a few specially chosen mountings for your collection. Make sure you have a look at the Teratomyrmex and Epopostruma frosti under the microscope. Both these species, by the way, are very rare." In a later note he wrote: "The species [ $T$. greavesi] appears to be rare in the ranges near Murwillumbah NE. NSW. Forages on low shrubs and in leaf litter. Nests in very moist places, usually in white-rotten timber. It is very easily mistaken for a small black Iridomyrmex." He also included a quotation from a personal communication he had received from Tom Greaves: " $T$. greavesi is a dominant ant in residual forest,' i.e., in the Jackall Ranges, about 75 miles north of Brisbane."

${ }^{1}$ Hymenoptera: Formicidae: Formicinae.

Manuscript received by the editor December 10, 1973 
Recently Dr. W. L. Brown sent us a worker of Teratomyrmex (see Fig. 7 and 8) together with several larvae. Given such a weird worker could one reasonably expect its larva to be somewhat bizarre also? We hoped it would. And we were disappointed: the larva is quite ordinary. Its profile is pogonomyrmecoid, a character shared with 19 other genera in the Formicinae; its mandibles are camponotoid in common with 23 other formicine genera. In fact, in our key to the larvae of the Formicidae (1974), in which most ant larvae were differentiated to genera or at least to tribes, we could only add Teratomyrmex to the residual lump of 22 undifferentiated genera: "Tribes Formicini, Gesomyrmecini, Gigantiopini, Melophorini and Plagiolepidini."

The index of specialization (see our 1974) for Teratomyrmex is 14; that of the tribe Formicini is 14. [The most specialized ant larvae - the Leptanillinae - have an index of 35 , while the Formicinae as a whole are less specialized with 17 . The index for the family as a whole is 22.]

\section{Genus Teratomyrmex McAreavey}

Body pogonomyrmecoid. Entire integument spinulose. Body hairs long and moderately numerous; of 3 types: denticulate; long, smooth and flexuous; 2- or 3-branched, smooth with the branches long and flexuous. Head hairs moderately numerous; unbranched, denticulate throughout most of length. Labrum deeply bilobed. Mandibles camponotoid. Maxillae with paraboloidal apex; palp a paxilla; galeae digitiform. Labrum subrectangular in anterior view; palp a short paxilla; opening of sericteries wide and salient.

Teratomyrmex sp. (near greavesi McAreavey) Fig. I-6. Length (through spiracles) about $3.7 \mathrm{~mm}$. Shape pogonomyrmecoid (i.e., diameter greatest near the middle of the abdomen, decreasing gradually toward head and more rapidly toward posterior end, which is rounded; thorax more slender and forming a rather stout neck which is curved ventrally) but abdomen rather slender. Anus posteroventral and with 2 small lips. Wing and gonopod vestiges present. Ten pairs of spiracles. Entire integument spinulose, the spinules most prominent on the venter of TI-3 and AI-AIII, sparse and scattered elsewhere. Body hairs moderately numerous and long. Of 3 types: (I) 0.075-0.15 mm long, unbranched and with numerous short denticles, longest and most numerous on the thorax; (2) $0.2-0.33 \mathrm{~mm}$ long, unbranched, smooth, very long, slender and flexuous, none on 

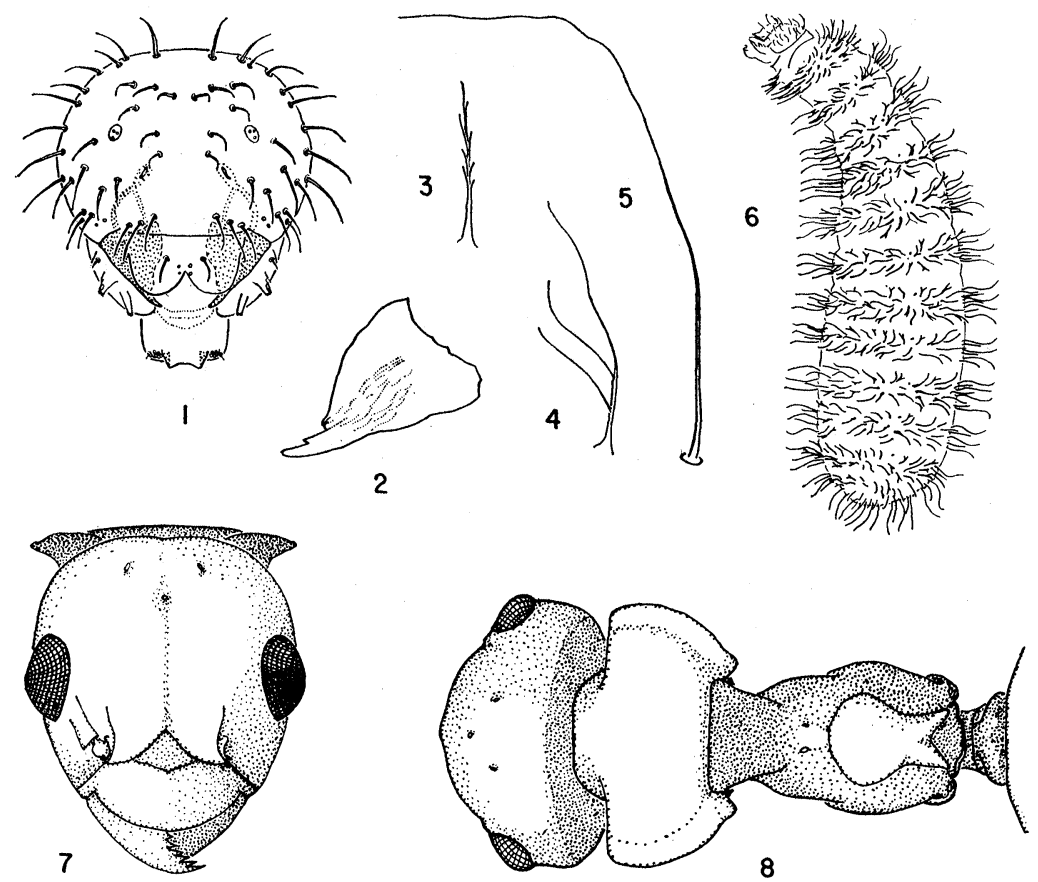

Textfigure $1-6$, larva. 1 , head in anterior view, $\times 71 ; 2$, left mandible in anterior view, $\times 145 ; 3-5$, three types of body hairs $\times 267 ; 6$, larva in side view, $\times 14$.

Textfigure 7 and 8, worker. 7 , head and dorsum of pronotum in anterior view, $\times 34 ; 8$, head, thorax and petiole in dorsal view, $\times 34$. 
'TI, more numerous on abdomen; (3) 0.09-0.15 mm long, 2- or 3branched, with long slender tips, on all somites. Cranium suboctagonal; broader than long. Antennae small, each a slight elevation with 3 sensilla, each of which bears a small spinule. Head hairs moderately numerous, rather long $(0.05-0.09 \mathrm{~mm})$ and rather stout, unbranched and with numerous fine denticles throughout length. Mouth parts large. Labrum bilobed; each lobe with 2 hairs about $0.05 \mathrm{~mm}$ long with small denticles and with 5 sensilla on and near the ventral border; posterior surface spinulose, the spinules in short to long rows, the rows radiating from each dorsolateral angle, and with 5 sensilla on each half near the midline. Mandibles camponotoid (i.e., subtriangular; base broad, width $2 / 3$ length; apex forming a round-pointed tooth; one small subapical tooth); anterior and posterior surfaces with numerous short longitudinal rows of minute spinules. Maxillae with the apex paraboloidal; palp a paxilla with 5 ( 3 apical and bearing a spinule each, I subapical and encapsulated, I lateral and bearing a spinule) sensilla; galea digitiform, with 2 apical sensilla. Labium subrectangular in anterior view; anterior surface with minute spinules in short rows; palp a short peg with 5 ( 3 apical and bearing a spinule each and 2 lateral - I encapsulated and I bearing a spinule) sensilla; opening of sericteries wide and salient, with 2 ventral projections. Hypopharynx densely spinulose, the spinules minute and arranged in numerous subparallel rows; the rows grouped in 2 subtriangles which have their bases near the middle.

Material studied: i4 larvae from Queensland: Cedar Creek Falls, Tamborine Mts., Ross \& Cavagnaro, 1962; courtesy of Dr. W. L. Brown.

\section{Literature Cited}

McAreavey, J. J.

1957. [Teratomyrmex gen. nov.] Mem. Nat. Mus. Vict. No. 21, p. 54-56. WheEler, G. C., and JeanetTe Wheeler.

1974. Ant larvae: review and synthesis. Mem. Entom. Soc. Washington [in press]. 

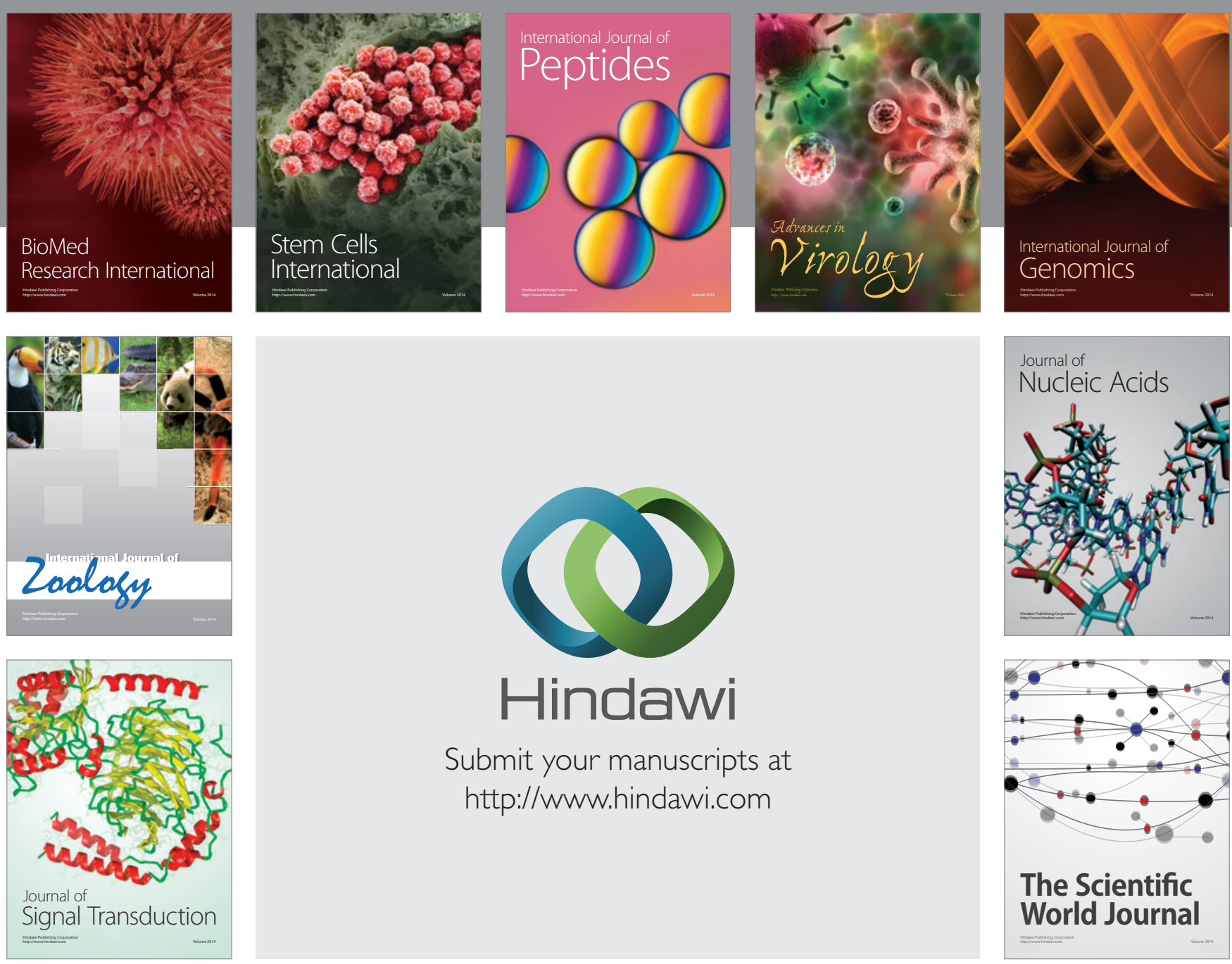

Submit your manuscripts at

http://www.hindawi.com
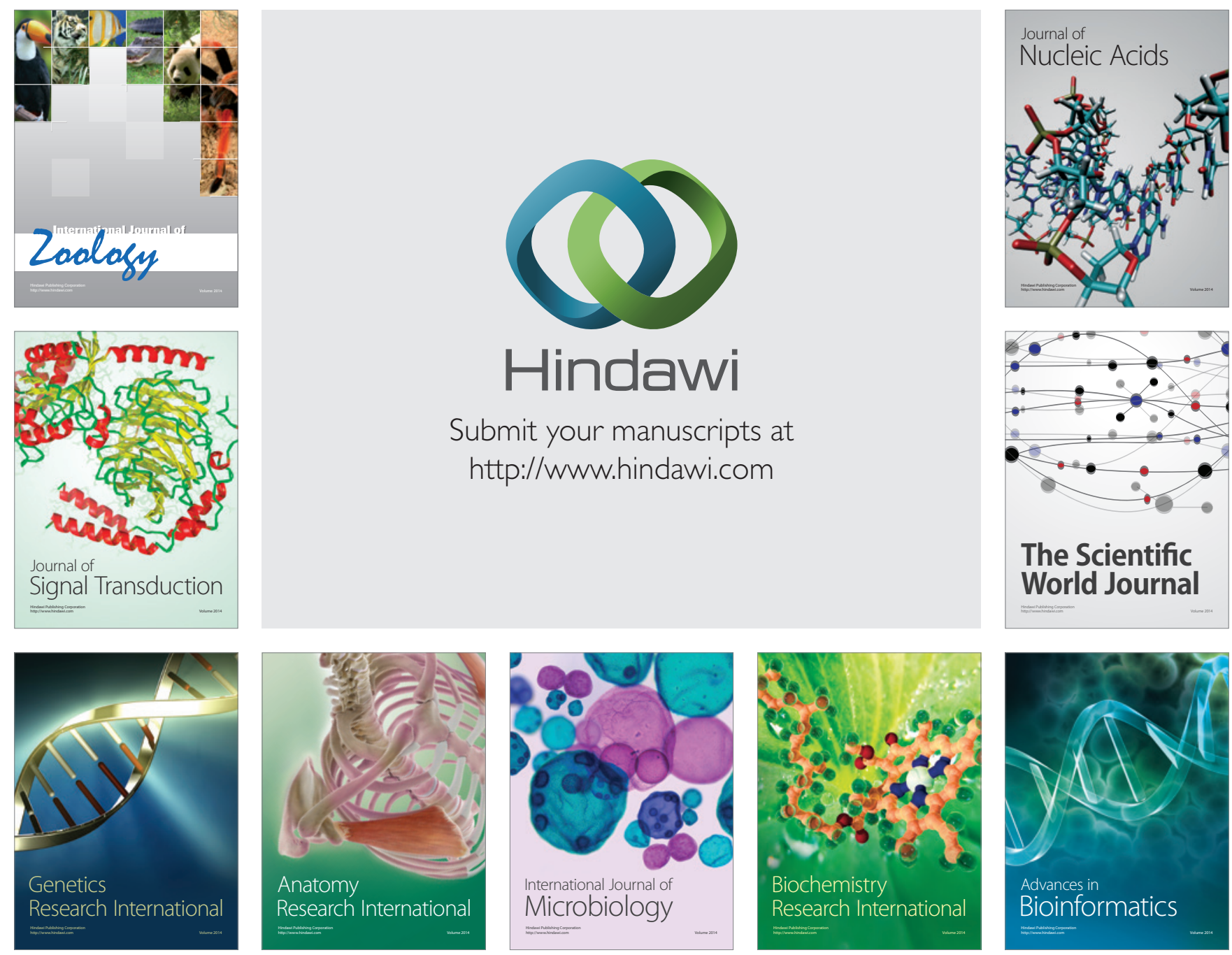

The Scientific World Journal
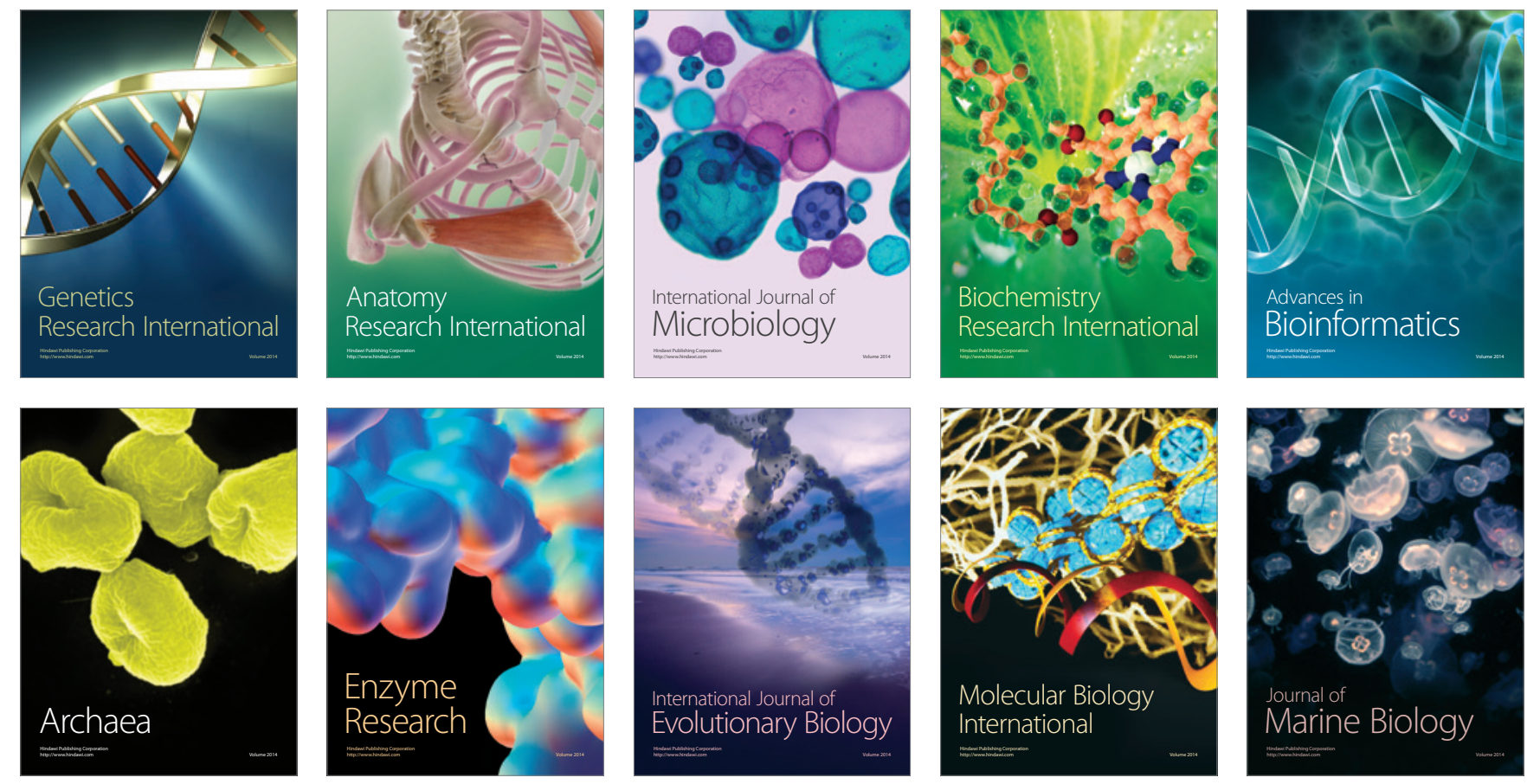